\title{
PERBANDINGAN STRATEGI INQUIRI DAN STRATEGI EKSPOSITORI TERHADAP HASIL BELAJAR MATEMATIKA SISWA
}

\section{COMPARISON OF INQUIRY STRATEGY AND EXPOSITORY STRATEGY TOWARDS STUDENTS MATHEMATICS LEARNING OUTCOMES}

\author{
Nurlinda Nurdin'1), Ilyas²), Nur Khalisah Latuconsina3), Ahmad Farham Majid4), \\ Muhammad Rusydi Rasyid5) \\ 1), 2), 3), 4), 5) Universitas Islam Negeri Alauddin Makassar, Fakultas Tarbiyah dan Keguruan \\ nurlinda.nurdin@gmail.com ${ }^{11}$, ilyas.ismail@uin-alauddin.ac.id²), nur.khalisah@uin-alauddin.ac.id ${ }^{3}$, \\ ahmad.farham@uin-alauddin.ac.id ${ }^{4}$, , muhammad.rusydi@uin-alauddin.ac.id(5)
}

\begin{abstract}
Abstrak
Tujuan penelitian ini adalah untuk mengetahui perbedaan hasil belajar matematika siswa yang diajar menggunakan strategi inquiri dan strategi ekspositori. Penelitian ini merupakan jenis penelitian Quasi Experimental dengan desain penelitian Pretest-Posttest Group Design. Populasi penelitian ini adalah seluruh peserta didik kelas VIII SMP Negeri 26 kota Makassar yang berjumlah 277 siswa. Teknik pengambilan sampel yang digunakan adalah teknik multiple random sampling. Instrumen yang digunakan untuk mengetahui hasil belajar siswa berupa tes essai sebanyak 5 item soal. Teknik analisis data yang digunakan adalah analisis statistik deskriptif dan analisis statistik inferensial dengan uji sampel $t$-test. Berdasarkan hasil analisis deskriptif diperoleh kesimpulan bahwa hasil belajar siswa yang menggunakan strategi inquiri lebih baik dibanding dengan hasil belajar yang menggunakan strategi ekspositori. Sedangkan berdasarkan hasil analisis inferensial menggunakan uji sampel $t$ test menunjukkan bahwa ada perbedaan signifikan antara strategi inquiri dan strategi ekspositori terhadap hasil belajar matematika siswa kelas VIII SMP Negeri 26 kota Makassar. Berdasarkan pengamatan peneliti pada hasil belajar strategi inquiri, siswa lebih aktif dan berusaha mencari solusi dari setiap masalah melalui interaksi dengan teman kelompoknya. Guru berperan sebagai fasilitator dan motivator dalam proses belajar mengajar. Sedangkan pada strategi ekspositori, keterlibatan siswa dalam proses belajar mengajar tidak terlalu nampak. Peran guru sangat dominan karena harus menjelaskan materi pelajaran.
\end{abstract}

Kata Kunci: hasil belajar matematika, strategi inquiri, strategi ekspositori

\begin{abstract}
The purpose of this study was to determine the differences in students' mathematics learning outcomes who were taught using an inquiry strategy and an expository strategy. This research is a Quasi Experimental type of research with a Pretest-Posttest Group Design research design. The population of this study were all students of class VIII SMP Negeri 26 Makassar, which amounted to 277 students. The sampling technique used is the multiple random sampling technique. The instrument used to determine student learning outcomes is in the form of an essay test of 5 items. The data analysis technique used is descriptive statistical analysis and inferential statistical analysis with sample t-test. Based on the results of the descriptive analysis, it was concluded that student learning outcomes using the inquiry strategy were better than those using the expository strategy. Meanwhile, based on the results of inferential analysis using the sample t-test, it shows that there is a significant difference between the inquiry strategy and the expository strategy on the mathematics learning outcomes of eighth grade students of SMP Negeri 26 Makassar. Based on the researcher's observations on the
\end{abstract}


learning outcomes of the inquiry strategy, students were more active and tried to find solutions to each problem through interaction with their group mates. The teacher acts as a facilitator and motivator in the teaching and learning process. While in the expository strategy, student involvement in the teaching and learning process is not very visible. The teacher's role is very dominant because they have to explain the subject matter.

Keywords: mathematical learning outcomes, inquiry strategies, expository strategies

How to Cite: Nurdin, N., Ilyas., Latuconsina, N., Majid, A.F., \& Rasyid, M.R. (2021). Perbandingan Strategi Inquiri dan Strategi Ekspositori terhadap Hasil Belajar Matematika Siswa. Al asma: Journal of Islamic Education, 3(2), 200-209.

\section{PENDAHULUAN}

Pendidikan memiliki peranan yang sangat penting dalam kehidupan berbangsa dan bernegara, yaitu untuk menjamin kelangsungan kehidupan dan perkembangan bangsa itu sendiri. Untuk mencapai tujuan tersebut telah banyak upaya yang dilakukan oleh pemerintah agar dapat meningkakan kualitas pendidikan. Kualitas pendidikan perlu ditingkatkan pada semua mata pelajaran termasuk mata pelajaran matematika (Muliani \& Wibawa, 2018). Sistem pembelajaran yang mengutamakan matematika dan ilmu pengetahuan dasar lainnya menjadi prasyarat bagi proses pendidikan untuk membentuk manusia yang mampu menghadapi tantangan masa depan. Seorang guru diharapkan dapat mewujudkan tujuan kurikulum pendidikan, salah satunya adalah meningkatkan kemampuan belajar siswa dengan merancang pembelajaran dan memilih metode ataupun strategi yang efektif dan efesien (Sumarni, Santoso, \& Suparman, 2018). Oleh karena itu, seorang guru harus mampu menerapkan startegi pembelajaran yang tepat karena hal tersebut merupakan salah satu faktor yang mempengaruhi hasil belajar siswa.

Strategi yang tepat maka tentunya akan mempengaruhi efektifitas serta efisiensi pembelajaran di kelas (Sartika, 2019). Guru memegang peranan penting dalam mengarahkan pembelajaran di kelas dengan menggunakan berbagai variasi strategi pembelajaran yang dapat membangkitkan minat belajar siswa. Dengan mengetahui berbagai macam strategi pembelajaran maka diharapkan seorang guru mampu menyampaikan materi pembelajaran dengan berbagai variasi sehingga tujuan pembelajaran dapat tercapai dan prestasi belajar siswa dapat meningkat. Namun, berdasarkan informasi yang diperoleh dari hasil wawancara guru matematika Kelas VIII di SMP Negeri 26 kota Makassar, diperoleh informasi bahwa selama proses pembelajaran matematika, guru belum memberdayakan seluruh potensi dirinya. Guru masih menerapkan proses pembelajaran langsung tanpa disertai strategi pembelajaran yang lebih menarik guna memperkuat pemahaman siswa sehingga sebagian besar siswa belum mampu mencapai kompetensi individual yang diperlukan dalam mengikuti pelajaran lanjutan. Sebagian siswa belum belajar hingga pada tingkat pemahaman. Siswa hanya mampu menghafal konsep dan teori, mereka belum mampu mengembangkan keterampilan dasar yang berguna bagi dirinya dalam kehidupan sehari-hari sehingga pada akhirnya mempengaruhi pencapaian hasil belajarnya yang masih berada di bawah rata-rata Kriteria Ketuntasan Minimal (KKM). Hal ini diperkuat oleh pernyataan Nadjamuddin et al. (2017) yang menegaskan bahwa strategi pembelajaran yang dipilih dapat berkontribusi secara optimal pada ketercapaian hasil belajar yang telah ditetapkan sebelumnya. 
Berdasarkan paparan di atas diketahui bahwa kurang efektifnya kegiatan belajar siswa lebih disebabkan pada pemanfaatan strategi pembelajaran yang masih minim, yang dimana seharusnya guru memiliki peran penting untuk menciptakan suasana pembelajaran yang kondusif bagi tumbuhnya partisipasi, komunikasi, interaksi belajar mengajar yang menyenangkan dan mencerdaskan. Mengingat karena cukup banyak strategi pembelajaran yang tersedia sehingga salah satu usaha yang dapat dilakukan adalah dengan menggunakan strategi pembelajaran inquiri dengan strategi pembelajaran ekspositori.

Strategi pembelajaran inquiri merupakan rangkaian kegiatan pembelajaran yang menekankan pada proses berpikir secara kritis dan analitis untuk mencari dan menemukan sendiri jawaban dari suatu masalah yang dipertanyakan, dimana proses berpikir itu sendiri biasa dilakukan melalui tanya jawab antara guru dan siswa (Hendracipta, Nulhakim, \& Agustini, 2017). Strategi pembelajaran ini sering juga dinamakan heuristic, yang berasal dari bahasa Yunani yaitu heuriskein yang berarti "saya menemukan" (Zulkifli, 2018). Menurut Jayadinata dan Gusrayani (2016) terdapat enam tahap pelaksanaan pembelajaran strategi inquiri yang berperan pada pembelajaran, yakni orientasi, merumuskan masalah, mengajukan hipotesis, mengumpulkan data, menguji hipotesis, dan merumuskan kesimpulan.

Langkah-langkah pembelajaran yang termasuk dalam model pembelajaran inquiri dapat menjadi salah satu alternatif dalam mengemas pembelajaran matematika untuk meningkatkan hasil belajar siswa. Sebagaimana beberapa hasil penelitian strategi inquiri sebelumnya, yaitu penelitian Hasibuan dan Sylvia (2020); Zulkifli (2018) bahwa dengan menerapkan strategi inquiri pada pembelajaran dapat meningkatkan hasil belajar peserta didik. Adapun penelitian Zulfikar dan Tayeb (2018) membandingkan strategi inquiry terbimbing dan strategi bebas modifikasi untuk mengetahui bagaimana peningkatan kemampuan pemecahan masalah matematis. Hasil penelitian menunjukkan bahwa metode inquiry lebih efektif meningkatkan kemampuan pemecahan masalah matematika dibandingkan strategi bebas termodifikasi.

Adapun strategi ekspositori menurut Hendracipta, Syachruroji, \& Hermawilda (2017) adalah kegiatan mengajar yang berpusat pada guru. Pembelajaran yang berlangsung menekankan kepada proses penyampaian materi secara verbal dari seorang guru kepada kelompok siswa dengan maksud agar siswa dapat menguasai materi pelajaran secara optimal. Menurut Hudoyo (2005) strategi ekspositori dapat meliputi gabungan metode ceramah, metode driil, metode tanya jawab, metode penemuan, dan metode peragaan. Penggunaan strategi ini siswa tidak perlu mencari dan menemukan sendiri fakta-fakta, konsep dan prinsip karena telah disajikan secara jelas oleh guru. Biasanya guru menyampaikan informasi mengenai bahan pengajaran dalam bentuk penjelasan dan penuturan secara lisan. Sehingga siswa diharapkan dapat menangkap dan mengingat informasi yang telah diberikan guru, serta mengungkapkan kembali apa yang dimilikinya melalui respons yang ia berikan pada saat diberikan pertanyaan oleh guru.

Kedua stretegi ini memiliki perbedaan yang cukup ekstrim, yakni pada strategi inquiri, siswa melalui eksperimen dituntut untuk mengumpulkan informasi, merumuskan hipotesis, dan mengujinya (Falahudin, Wigati, \& Pujiastuti, 2016). Sehingga hal baru atau hasilnya belum diketahui oleh guru. Pada strategi inquiri, siswa direncanakan menemukan sesuatu, tetapi pada strategi inquiri proses penemuannya itu yang penting, hasilnya adalah nomor dua. Sedangkan strategi ekspositori, paradigma pembelajaran cenderung berpusat 
pada guru (teacher centered) (Aminullah, 2021). Sehingga guru memegang kendali dalam pelaksanaan proses pembelajaran dan siswa hanya menerima apa yang disampaikan oleh guru tanpa melakukan suatu kegiatan yang bermakna. Perbedaan kedua strategi ini menjadi hal yang dapat memunculkan hal-hal baru dalam proses pembelajaran, utamanya pada hasil belajar yang diperoleh siswa. Oleh karena itu, perbandingan penerapan strategi inquiri dan ekspositori perlu dilakukan untuk melihat bagaimana dampak dari penerapan kedua strategi tersebut terhadap hasil belajar siswa.

Berpedoman pada penjelasan di atas, maka tujuan penelitian ini adalah untuk mengetahui perbedaan hasil belajar matematika siswa yang diajar menggunakan strategi inquiri dan strategi ekspositori.

\section{METODE PENELITIAN}

Jenis penelitian yang digunakan adalah penelitian kuantitatif dengan pendekatan Quasi Experimental. Penelitian ini dilakukan di SMP Negeri 26 kota Makassar. Desain penelitian yang digunakan adalah Pretest-Posttest Group Design. Desain ini terdapat dua kelompok yang dipilih secara random, kemudian diberikan pretest untuk mengetahui adakah perbedaan antara kelompok eksperimen 1 dan kelompok eksperimen 2. Kelompok eksperimen 1 adalah kelompok yang diterapkan dengan menggunakan strategi inquiri dan kelompok eksperimen 2 adalah kelompok yang menggunakan strategi ekspositori. Populasi dalam penelitian ini adalah seluruh siswa kelas VIII SMP Negeri 26 kota Makassar yang berjumlah 277 siswa yang terdiri atas 9 kelas dengan semua kelas penyebaran yang homogen. Teknik pengambilan sampel yang digunakan dalam penelitian ini adalah multiple random sampling. Berdasarkan teknik pengambilan sampel, maka sampel penelitian terpilih yaitu siswa kelas VIII-5 dengan jumlah siswa 20 orang sebagai kelas eksperimen 1 dan kelas VIII-7 dengan jumlah 20 orang sebagai kelas eksperimen 2.

Instrumen yang digunakan dalam penelitian ini adalah tes penilaian hasil belajar. Bentuk tes yang digunakan adalah soal essai. Jumlah item soal sebanyak 5 butir soal. Pengolahan data hasil penelitian digunakan dua teknik statistik, yaitu statistik deskriptif dan statistik inferensial. Teknik statistik inferensial yang digunakan yaitu uji perbandingan sampel $t$-test.

\section{HASIL DAN PEMBAHASAN}

\section{Deskripsi Hasil Penelitian}

Berdasarkan hasil analisis statistik deskriptif pada hasil belajar matematika siswa kelas eksperimen 1 (VIII-5) yang diajar dengan menggunakan strategi inquiri setelah dilakukan posttest, yang dapat dilihat pada tabel berikut:

Tabel 1. Hasil Belajar Posttest pada Kelas Eksperimen 1

\begin{tabular}{ccccc}
\hline No & Interval & F & $\begin{array}{c}\text { Persentase } \\
(\mathbf{\% )}\end{array}$ & Kategori \\
\hline 1 & $68-72$ & 4 & 20 & Sedang \\
2 & $73-77$ & 2 & 10 & Rendah \\
3 & $78-82$ & 1 & 5 & Rendah \\
4 & $83-87$ & 6 & 30 & Tinggi \\
5 & $88-92$ & 7 & 35 & Tinggi \\
\hline & Jumlah & $\mathbf{2 0}$ & $\mathbf{1 0 0 , 0 0}$ & \\
\hline
\end{tabular}


Pada tabel 1, diketahui bahwa siswa yang memperoleh nilai posttest dengan interval 83-87 sebanyak 6 siswa dan nilai dengan interval 88-92 sebanyak 7 siswa sehingga jumlah seluruhnya terdapat 13 siswa dengan total persentase sebesar 65\%. Persentase ini berada pada kategori tinggi. Siswa yang memperoleh nilai posttest dengan interval 68-72 berjumlah 4 siswa dengan persentase sebesar $20 \%$. Persentase ini berada pada kategori sedang. Siswa yang memperoleh nilai posttest dengan interval antara 73-77 dan 78-82 masing-masing sebanyak 2 siswa dan 1 siswa sehingga total seluruhnya terdapat 3 siswa dengan total persentase sebesar 15\%. Persentase ini berada pada kategori rendah. Penyajian hasil belajar posttest pada kelas eksperimen 1 juga dapat dilihat pada diagram lingkaran berikut.

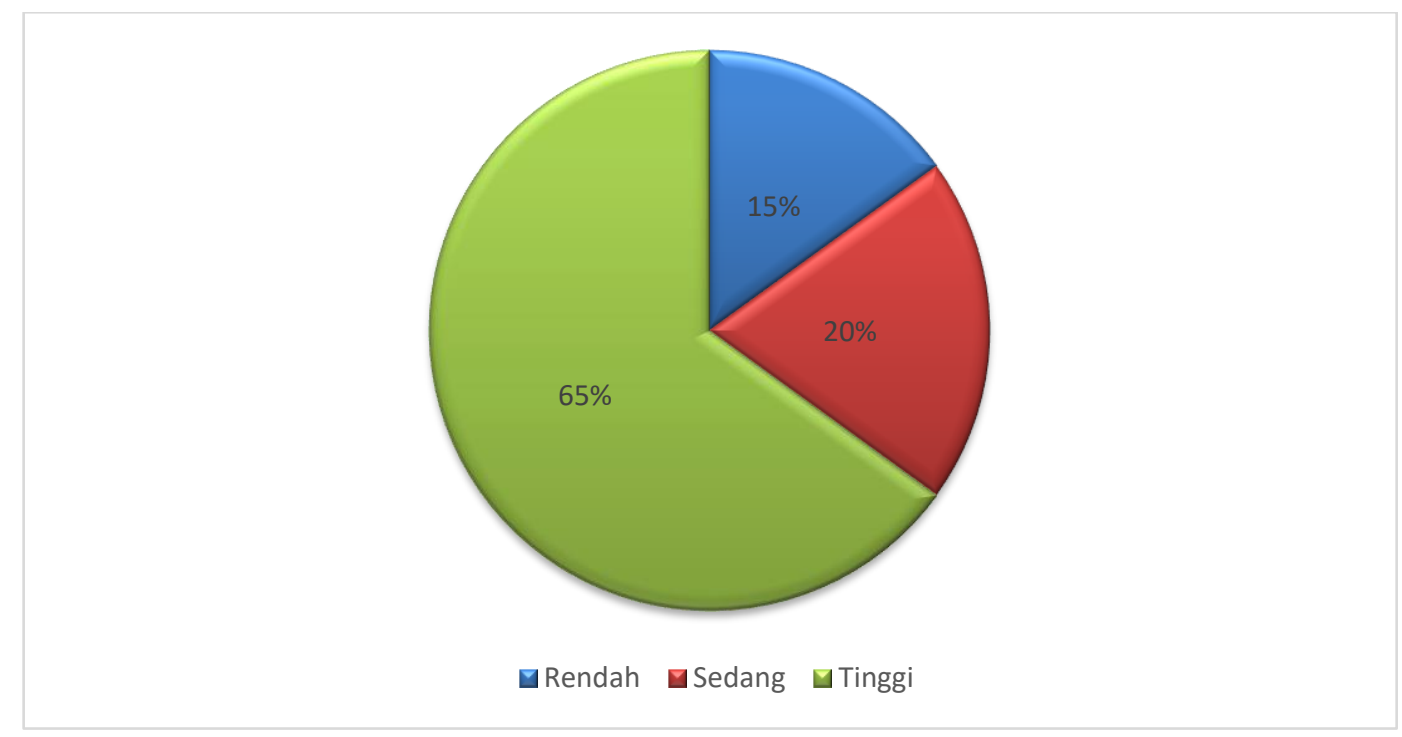

Gambar 1. Persentase Kategori Hasil Belajar Matematika (Posttest) Kelas Eksperimen 1

Berdasarkan tes yang diberikan kepada siswa untuk kelas eksperimen 2 setelah penggunaan strategi ekspositori di kelas VIII-7 didapatkan hasil posttest sebagai berikut:

Tabel 2. Hasil Belajar Posttest pada Kelas Eksperimen 2

\begin{tabular}{ccccc}
\hline No & Interval & F & $\begin{array}{c}\text { Persentase } \\
\mathbf{( \% )}\end{array}$ & Kategori \\
\hline 1 & $64-68$ & 3 & 15 & Rendah \\
2 & $69-73$ & 1 & 5 & Rendah \\
3 & $74-78$ & 2 & 10 & Rendah \\
4 & $79-83$ & 7 & 35 & Tinggi \\
5 & $84-88$ & 7 & 35 & Tinggi \\
\hline & Jumlah & $\mathbf{2 0}$ & $\mathbf{1 0 0 , 0 0}$ & \\
\hline
\end{tabular}

Pada tabel 2, diketahui bahwa siswa yang memperoleh nilai posttest dengan interval 79-83 sebanyak 7 siswa dan nilai dengan interval 84-88 sebanyak 7 siswa sehingga total seluruhnya terdapat 14 siswa dengan total persentase sebesar $70 \%$. Persentase ini berada pada kategori tinggi. Siswa yang memperoleh nilai posttest dengan interval 64-68, 69-73, dan 74-78 masing-masing sebanyak 3 siswa dengan persentase sebesar 15\%, 1 siswa dengan persentase sebesar $5 \%$, dan 2 siswa dengan persentase sebesar $10 \%$ sehingga total seluruhnya terdapat 6 siswa dengan persentase total sebesar $30 \%$. Ketiga persentase untuk 
setiap interval tersebut berada pada kategori rendah. Penyajian hasil belajar posttest pada kelas eksperimen 2 juga dapat dilihat pada diagram lingkaran berikut.

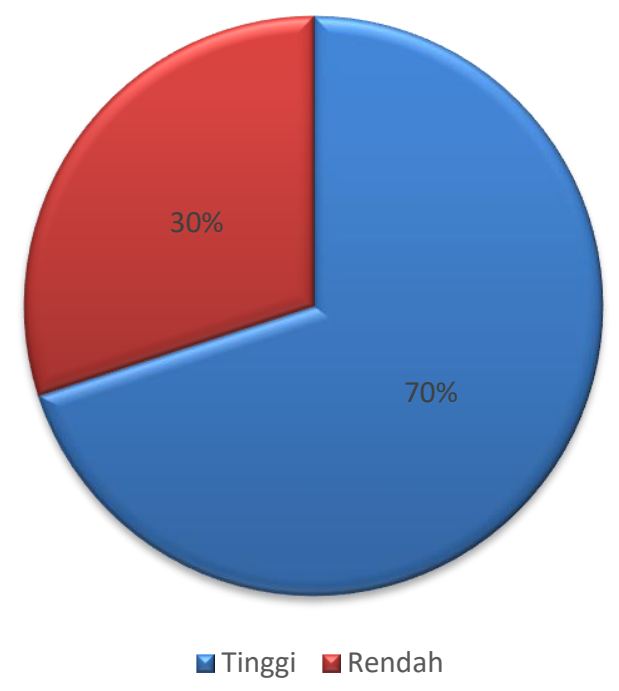

Gambar 2. Persentase Kategori Hasil Belajar Matematika (Posttest) Kelas Eksperimen 2

Sebelum melakukan uji perbandingan yaitu uji t ( $t$-test), terlebih dahulu beberapa prasyarat uji parametrik harus terpenuhi, yaitu uji normalitas dan uji homogenitas. Pengujian normalitas bertujuan untuk menyatakan apakah data skor hasil belajar matematika pokok bahasan aljabar untuk masing-masing kelas eksperimen 1 dan kelas eksperimen 2 dari populasi berdistribusi normal. Sedangkan uji homogenitas bertujuan untuk melihat apakah data pada kedua kelompok memiliki variansi yang sama (homogen) atau tidak.

Berdasarkan hasil analisis untuk uji normalitas pada SPSS diperoleh hasil analisis one-sample kolmogorov-smirnov test data untuk kelompok eksperimen 1 yang diajar dengan strategi inquiri, maka diperoleh nilai $\mathrm{p}$ untuk pretest $=0,274$ dan nilai $\mathrm{p}$ untuk posttest $=$ 0,341 untuk $\alpha=0.05$, hal ini menunjukkan $p>\alpha$. Ini berarti data skor hasil belajar matematika untuk kelompok eksperimen 1 yang diajar dengan strategi inquiri berdistribusi normal. Sedangkan hasil analisis data untuk kelompok eksperimen 2 yang diajar dengan strategi ekspositori, diperoleh nilai p untuk pretest $=0,860$ dan nilai p untuk posttest $=0,542$ untuk $\alpha=0.05$, hal ini menunjukkan $p>\alpha$. Ini berarti data skor hasil belajar matematika untuk kelompok eksperimen 2 yang diajar dengan menggunakan strategi ekspositori berdistribusi normal, sehingga data kedua kelompok tersebut berdistribusi normal.

Berdasarkan hasil analisis untuk uji homogenitas diperoleh nilai $F_{\text {hitung }}$ adalah 1,10 sedangkan nilai $F_{\text {tabel }}$ adalah 3,025. Sehingga $F_{\text {hitung }} \leq F_{\text {tabel } \alpha(0,05)}$ atau 1,10 $\leq 3,025$ maka $H_{O}$ yang menyatakan bahwa populasinya homogen diterima.

Berdasarkan hasil pengujian uji t ( $t$-test) maka diperoleh nilai $t_{\text {hitung }}=2,419>$ $t_{\text {tabel }}=2,024$ dengan taraf nyata $\alpha=0,05 \mathrm{dan} \mathrm{dk}=38$ sehingga $t_{\text {hitung }}$ berada pada daerah penerimaan $H_{0}$, yang berarti hipotesis $H_{O}$ ditolak dan hipotesis $H_{1}$ diterima. Sehingga dapat dikatakan bahwa dengan memanfaatkan strategi inquiri dengan strategi ekspositori dapat meningkatkan hasil belajar siswa pada mata pelajaran matematika di kelas VIII SMP Negeri 26 kota Makassar. Hal tersebut menunjukkan bahwa ada perbedaan yang berarti antara 
kelas eksperimen 1 dan kelas eksperimen 2 dengan diterapkannya strategi inquiri dengan strategi ekspositori terhadap hasil belajar siswa.

\section{Pembahasan}

Data yang telah diperoleh merupakan hasil pelaksanaan penelitian pada kelas eksperimen 1 yang menggunakan strategi inquiri dan kelas eksperimen 2 yang menggunakan strategi ekspositori pada siswa kelas VIII-5 dan VIII-7 SMP Negeri 26 kota Makassar yang berjumlah 40 siswa. Instrumen penelitian yang digunakan adalah tes essai berjumlah 5 item soal. Setelah memberikan tes tersebut kepada siswa diperoleh data yang selanjutnya akan dianalisis.

Hasil analisis data yang diperoleh yaitu pada kelas eksperimen 1 diperoleh rata-rata hasil belajar pada pretest sebesar 59,5 sedangkan rata-rata hasil belajar pada posttest sebesar 82,5 . Kategori pretest hasil belajar siswa tertinggi dengan persentase $60 \%$ pada kelas eksperimen 1 berada pada kategori rendah. Sedangkan kategori posttest hasil belajar siswa tertinggi dengan persentase $65 \%$ pada kelas eksperimen 1 berada pada kategori tinggi. Jadi, dapat disimpulkan bahwa terdapat peningkatan hasil belajar matematika siswa sebelum dan sesudah menggunakan strategi inquiri. Hal ini didukung oleh penelitian Amijaya, Ramdani, \& Merta (2018) bahwa kelas yang menggunakan strategi inquiri, peserta didik diberikan kesempatan untuk terlibat langsung dalam kegiatan pembelajaran sehingga peserta didik termotivasi untuk belajar dan proses pembelajaran menjadi berkesan. Selain itu, Silaban (2019) menyimpulkan bahwa model pembelajaran inquiri dapat membuat siswa menjadi aktif untuk mencari dan menemukan penyelesaian permasalahan yang diajukan sehingga dengan demikian hasil belajar siswa dapat meningkat.

Hasil analisis data yang diperoleh pada kelas eksperimen 2 yaitu pada pretest diperoleh rata-rata sebesar 59 sedangkan pada posttest diperoleh rata-rata sebesar 79,5. Kategori pretest hasil belajar siswa tertinggi dengan persentase $45 \%$ pada kelas eksperimen 2 berada pada kategori rendah. Sedangkan kategori posttest hasil belajar siswa tertinggi dengan persentase $70 \%$ pada kelas eksperimen 2 berada pada kategori tinggi. Jadi, dapat disimpulkan bahwa terjadi peningkatan hasil belajar sebelum dan sesudah penggunaan strategi ekspositori. Hasil ini berbeda dengan penelitian Pratiwi, Wijayati, \& Mahatmanti (2019) yang menyimpulkan bahwa penerapan strategi ekspositori dalam sebuah kelas, tidak memberikan peningkatan hasil belajar kepada peserta didik. Pada kenyataannya, strategi pembelajaran ekspositori sekali-sekali juga dibutuhkan oleh peserta didik, seperti guru menjelaskan materi kemudian siswa diberi kesempatan untuk menjawab beberapa soal yang sesuai dengan level kognitif (Kusumawati dan Irwanto, 2016). Hal ini juga didukung oleh hasil penelitian yang diperoleh Ragin, Refando, \& Utami (2020) yang menyimpulkan penggunaan strategi ekspositori dalam pembelajaran matematika memiliki pengaruh besar untuk meningkatkan hasil belajar siswa.

Berdasarkan hasil deskriptif tersebut, maka dilakukan uji prasyarat yaitu uji normalitas dan uji homogenitas sebelum melakukan uji hipotesis terhadap hasil belajar posttest pada kelas eksperimen 1 yang menggunakan strategi inquiri dan kelas eksperimen 2 yang menggunakan strategi ekspositori dengan menggunakan bantuan software SPSS. Hasil uji normalitas dan uji homogen posttest pada kelas eksperimen 1 dan eksperimen 2 menunjukkan bahwa data skor hasil belajar matematika siswa pada kelas VIII SMP Negeri 26 kota Makassar berasal dari populasi yang berdistribusi normal dan homogen. 
Uji prasyarat terpenuhi, maka peneliti kemudian melanjutkan analisis data secara inferensial untuk menguji hipotesis penelitian. Hasil pengujian hipotesis dengan menggunakan uji sampel $t$-test menunjukkan bahwa terdapat perbedaan signifikan antara strategi inquiri dan strategi ekspositori terhadap hasil belajar matematika siswa kelas VIII SMP Negeri 26 kota Makassar.

Berdasarkan rata-rata hasil belajar siswa kelas ekperimen 1 dan kelas eksperimen 2 dapat disimpulkan bahwa perbedaan hasil belajar matematika siswa yang diajar dengan menggunakan strategi inquiri lebih meningkat dibandingkan dengan siswa yang diajar dengan strategi ekspositori di kelas VIII SMP Negeri 26 kota Makassar. Hal ini disebabkan karena strategi inquiri merupakan proses untuk memperoleh dan mendapatkan informasi dengan melakukan observasi dan atau eksperimen untuk mencari jawaban atau memecahkan masalah terhadap pertanyaan atau rumusan masalah dengan menggunakan kemampuan berpikir kritis dan logis (Hosnah, Sudarti, \& Subiki, 2019). Penelitian yang telah dilakukan oleh Sukma, Komariyah, \& Syam (2016) yang juga mengkaji strategi inquiri ini menunjukkan bahwa keterampilan siswa meningkat dan motivasi belajarnya juga meningkat. Jadi meskipun strategi inquiri berpusat pada siswa, namun guru tetap memegang peranan bukan hanya sekedar perancang, tetapi pembimbing, fasilitator, serta motivator bagi siswa. Guru memiliki kewajiban dalam mengiring siswa untuk melakukan kegiatan. Guru juga harus merangsang siswa untuk mengajukan pertanyaan terhadap materi yang sedang dipelajari. Lahadisi (2014) juga menambahkan bahwa strategi inkuiri menempatkan guru bukan sebagai sumber belajar, akan tetapi sebagai fasilitator dan motivator belajar siswa.

Berdasarkan pengamatan peneliti ternyata terdapat perbedaan mendasar antara strategi inquiri dengan strategi ekspositori. Pada strategi inquiri, siswa lebih aktif mengkonstruksi jawaban. Mereka berusaha mencari solusi dari setiap masalah melalui interaksi dengan teman kelompoknya. Dengan demikian, peranan guru tidak terlalu dominan. Guru berperan sebagai fasilitator dan motivator dalam proses belajar mengajar. Pada strategi ekspositori, keterlibatan siswa dalam proses belajar mengajar tidak terlalu nampak. Peran guru sangat dominan karena harus menjelaskan materi pelajaran. Hal ini mengakibatkan siswa cenderung untuk menghafal dan menimbulkan rasa jenuh pada siswa sehingga kurang termotivasi untuk belajar.

\section{SIMPULAN}

Berdasarkan hasil penelitian dan pembahasan sebelumnya, maka diperoleh kesimpulan bahwa terdapat perbedaan hasil belajar matematika siswa yang diajar menggunakan strategi inquiri dan strategi ekspositori. Berdasarkan hasil analisis deskriptif diperoleh kesimpulan bahwa peningkatan hasil belajar siswa yang menggunakan strategi inquiri lebih baik dibanding dengan hasil belajar yang menggunakan strategi ekspositori. Sedangkan berdasarkan hasil analisis inferensial menggunakan uji sampel t-test menunjukkan bahwa ada perbedaan signifikan antara strategi inquiri dan strategi ekspositori terhadap hasil belajar matematika siswa. Berdasarkan pengamatan peneliti pada hasil belajar strategi inquiri, siswa lebih aktif dan berusaha mencari solusi dari setiap masalah melalui interaksi dengan teman kelompoknya. Guru berperan sebagai fasilitator dan motivator dalam proses belajar mengajar. Sedangkan pada strategi ekspositori, 
keterlibatan siswa dalam proses belajar mengajar tidak terlalu nampak. Namun, di sisi lain terlihat bahwa peran guru sangat dominan karena harus menjelaskan materi pelajaran.

\section{DAFTAR PUSTAKA}

Amijaya, L. S., Ramdani, A., \& Merta, I. W. (2018). Pengaruh Model Pembelajaran Inkuiri Terbimbing Terhadap Hasil Belajar dan Kemampuan Berpikir Kritis Peserta Didik. Jurnal Pijar Mipa, 13(2), 94. https://doi.org/10.29303/jpm.v13i2.468

Aminullah. (2021). Interaksi Model Pembelajaran Inkuri Terbimbing vs Ekspositori dan Motivasi Belajar Terhadap Hasil Belajar IPA Siswa. MAHAGURU: Jurnal Pendidikan Guru Sekolah Dasar, 1(1), 28-34.

Falahudin, I., Wigati, I., \& Pujiastuti, A. (2016). Pengaruh Model Pembelajaran Inkuiri Terbimbing Terhadap Kemampuan Berpikir Kritis Siswa pada Pembelajaran Materi Pengelolaan Lingkungan di SMP Negeri 2 Tanjung Lago, Kabupaten Banyuasin. Bioilmi: Jurnal Pendidikan, 2(2), 92-101. https://doi.org/10.19109/bioilmi.v2i2.1133

Hasibuan, R. F., \& Sylvia, I. (2020). Upaya Peningkatan Hasil Belajar Siswa Melalui Penerapan Strategi Inquiry pada Pembelajaran Sosiologi Kelas XI IPS di SMAN 1 Batang Gasan. Jurnal Sikola: Jurnal Kajian Pendidikan Dan Pembelajaran, 2(1), 44-52.

Hendracipta, N., Nulhakim, L., \& Agustini, S. M. (2017). Perbedaan Kemampuan Berpikir Kritis Matematis Melalui Penerapan Model Inkuri Terbimbing di Sekolah Dasar. JPSD, $3(2), 215-227$.

Hendracipta, N., Syachruroji, A., \& Hermawilda, H. (2017). Perbedaan Hasil Belajar Siswa Antara yang Menggunakan Srategi Inkuiri dengan Strategi Ekspositori. Jurnal Pendidikan Sekolah Dasar, 3(1), 33. https://doi.org/10.30870/jpsd.v3i1.1137

Hosnah, W. M., Sudarti, \& Subiki. (2019). Pengaruh Model Pembelajaran Inkuiri Terbimbing Terbahap Hasil Belajar Fisika di SMA. Chemistry Education Practice, 2(2), 190-195.

Hudoyo, H. (2005). Teori Belajar untuk Pengajaran Matematika. Depdikbud.

Jayadinata, A. K., \& Gusrayani, D. (2016). Pengaruh Model Pembelajaran Inkuiri Terbimbing Terhadap Kemampuan Berpikir Kritis Siswa Pada Materi Energi Bunyi. Jurnal Pena Ilmiah, 1(1), 51-60. https://doi.org/10.23819/pi.v1i1.2931

Kusumawati, E., \& Irwanto, R. A. (2016). Penerapan Metode Drill untuk Meningkatkan Kemampuan Pemecahan Masalah Matematis Siswa Kelas VIII SMP. EDU-MAT Jurnal Pendidikan Matematika, 4(April), 49-57.

Lahadisi. (2014). Inkuiri: Sebuah Strategi Menuju Pembelajaran Bermakna. Jurnal Al-Ta'dib, $7(2), 85-98$.

Muliani, N. K. D., \& Wibawa, M. C. (2018). Pengaruh Model Pembelajaran Inkuiri Terbimbing terhadap Hasil Belajar. Science and Physics Education Journal (SPEJ), 2(1), 1-10. https://doi.org/10.31539/spej.v2i1.333

Nadjamuddin, L., Degeng, I. N. S., Dwijogo, W. D., \& Ali, M. N. (2017). Pengaruh Strategi Pembelajaran dan Gaya Berpikir terhadap Hasil Belajar Sejarah Siswa SMA. Edcomtech: Jurnal Kajian Teknologi Pendidikan, 2(1), 41-54.

Pratiwi, K. F., Wijayati, N., \& Mahatmanti, F. W. (2019). Pengaruh Model Pembelajaran Inkuiri Terbimbing Berbasis Penilaian Autentik Terhadap Hasil Belajar Siswa. Jurnal Inovasi Pendidikan Kimia, 13(1).

Ragin, G., Refando, A., \& Utami, D. (2020). Implementasi Strategi Pembelajaran Ekspositori 
untuk Meningkatkan Hasil Belajar Matematika di Sekolah Dasar. Jurnal Pendidikan Dan Dakwah, 2(1), 54-60. https://ejournal.stitpn.ac.id/index.php/pandawa

Sartika, R. (2019). Pengaruh Strategi Pembelajaran dan Motivasi Belajar terhadap Hasil Belajar Akidah Akhlak Siswa MIN SEI Medan. Jurnal ANSIRU PAI, 3(1), 102-116.

Silaban, P. J. (2019). Penerapan Model Pembelajaran Inkuiri untuk Meningkatkan Hasil Belajar Siswa pada Mata Pelajaran Matematika di Kelas VI SD Negeri 066050 Medan Tahun Pembelajaran 2018/2019. Jurnal Ilmiah Aquinas, 2(1), 107-126.

Sukma, Komariyah, L., \& Syam, M. (2016). Pengaruh Model Pembelajaran Inkuiri Terbimbing (Guided Inquiry) dan Motivasi Terhadap Hasil Belajar Fisika Siswa. Saintifika, 18(1), 59-63.

Sumarni, S., Santoso, B. B., \& Suparman, A. R. (2018). Pengaruh Model Pembelajaran Inkuiri Terbimbing Terhadap Hasil Belajar Kognitif Peserta Didik. Jurnal Komunikasi Pendidikan, 1(1), 59. https://doi.org/10.32585/jkp.v1i1.17

Zulfikar, M., \& Tayeb, T. (2018). Perbandingan Penerapan Metode Inquiry Terbimbing Dan Metode Inquiry Bebas Termodifikasi Terhadap Kemampuan Pemecahan Masalah Matematika Siswa.

Zulkifli. (2018). Penerapan Strategi Pembelajaran Inquiry dengan Pendekatan CTL (Contextual Teaching and Learning) untuk Meningkatkan Hasil Belajar Matematika Siswa Kelas VIII-D SMPN 4 Tambah. Jurnal PAJAR (Pendidikan Dan Pengajaran) Program Studi Pendidikan Guru Sekolah Dasar FKIP Universitas Riau, 2(2), 156-165. 